\title{
GROWTH RESPONSES OF THE GIANT LAND SNAIL, ARCHACHATINA MARGINATA TO VARIOUS FORMULATIONS OF FEEDS
}

\author{
OLUMUYIWA TEMITOPE OMOTOSO
}

Department of Zoology, University of Ado-Ekiti, P.M.B. 5363, Ado-Ekiti, Nigeria.

(Submitted: 13 March 2004; Accepted: 31 October 2004)

\begin{abstract}
Archachatina marginata hatchlings (mean weight $5 \pm 0.1 \mathrm{~g}$ ) were distributed randomly into four dietary groups labelled A-D and fed for eight weeks on various feed formulations. Diet A was used as control while diets B, C and D were tested for their effects on the growth of snails. All the diets contributed to the developments of the snails but the snails recorded more growth in diets C and D. Also, the same trend was recorded for shell length and aperture length. An average weight gain recorded for snails fed with diets A, B, C and D are $14 \pm 4 \mathrm{~g}, 15 \pm 3 \mathrm{~g}$, $25 \pm 2 \mathrm{~g}$ and $31 \pm 1 \mathrm{~g}$ respectively. Shell length in snails fed with diet A, B, C and D are $3.3 \mathrm{~cm}, 4.1 \mathrm{~cm}, 6.3 \mathrm{~cm}$ and 6.5 $\mathrm{cm}$ respectively. Aperture length recorded for the snails fed with the diets A, B, C and D are $2 \mathrm{~cm}, 2.4 \mathrm{~cm}, 3 \mathrm{~cm}$ and $3.6 \mathrm{~cm}$ respectively. In the control trial ( $\operatorname{diet} \mathrm{A})$, the shell of snails were fragile and brittle while those of the snails fed with diets B, C and D were very hard.
\end{abstract}

Keywords: Archachatina marginata, aperture, feed formulations.

\section{Introduction}

Snails are members of the phylum Mollusca, the second largest animal phylum with about 80,000 living and 35,000 fossil species (Yoloye, 1988; Cooper and Knowler, 1991). The genera Archachatina, Achatina and Limicolaria are well known edible land snails in Nigeria (Alexander, 1997). Becquaert (1950) reported that the genus Archachatina comprises members with wide bulbous or dome-shaped summit of the shell.

The importance of food for the growth and developments of snails have been emphasized by so many workers. The roles of vegetable foods, fruits, commercial feeds and calcium have been reported in snails (Ebenso and Okafor, 2002; Ebenso, 2003; Ejidike, 2004). Thompson and Cheney (1996) reported that $40 \%$ limestone flour promoted good growth in Helix aspersa. Murphy (2001) reported that the higher the protein levels in the diets of snails the faster the snail would put on weight. Thompson and Cheney (1996) reported that snails cherished apple, carrot, apricot, beans, cabbage, lettuce, cucumber and sweet peas. They reported further that poultry mash was the best feed for hatchlings.

The main objective of this study was to determine the importance of different diet formulations on the developments of edible tropical land snail Archachatina marginata.

\section{Materials and Methods}

(a) Collection of feed components

Water leaves, lettuce and moderately ripe pawpaw were bought from farmers on their farms at Federal Polytechnic Road, Ado-Ekiti in Ekiti State of Nigeria. Oyster shells were bought from artisanal fishermen from Lagos beach. The oyster shells were thoroughly washed in distilled water to remove traces of heavy metals and salts that might have settled on them. The oyster shells were sun-dried for 7 days outside the laboratory before the laboratory blender was used to pulverized them into powders. The ground powder was sieved with wire mesh of size $0.20 \mathrm{~mm}$ in the laboratory.

\section{(b) Collection and handling of snails}

Adult giant land snails, Archachatina marginata, were purchased from farmers at Erinfun, Federal Polytechnic Road, Ado-Ekiti in Ekiti State of Nigeria. Wooden boxes $(90 \times 60 \times 45 \mathrm{~cm})$ were filled with $2 / 3$ rich humus soil and stones (Cooper and Knowler, 1991). Wire mesh was used to cover the boxes. The boxes were kept under shade trees outside the laboratory and more fresh leaves were used to cover them. The snails were given food every two days and the remnants were removed and replaced with new ones. The snails were allowed to spawn naturally 
in the boxes. After laying their eggs, the snails were removed to new boxes and the boxes were covered with clear rigid plastic sheets which provided area of attachment for the newly emerged snails. Adult snails were relocated to new boxes after spawning and the growth of the eggs were monitored until the emergence of new offspring (hatchlings).

\section{(c) Formulation of feed}

Four feed formulations were used for the study. Four experimental diets were formulated as shown in Table 1. A total of 120 adult snails, A. marginata of average sizes (250-400 g) were randomly distributed into three dietary groups and introduced into the rearing boxes. Diets B and C were well pulverized for easy utilization by the snails.

Table 1. Experimental feed formulations for snails.

\begin{tabular}{|l|l|l|l|l|}
\hline Diet & \multicolumn{1}{|c|}{ A } & \multicolumn{1}{c|}{ B } & \multicolumn{1}{c|}{ C } & \multicolumn{1}{c|}{ D } \\
\hline Composition & $50 \%$ & $10 \%$ & Layers mash & Broiler \\
& water & Pawpaw, & consisting 5\% & finisher \\
& leaves, & $53 \%$ & layer & consisting \\
& $50 \%$ & lettuce, & concentrate, & $7 \%$ broiler \\
& lettuce & $10 \%$ & $10 \%$ corn & concentrate, \\
& & carrots, & meal. 15\% & $52 \%$ corn, \\
& $20 \%$ water & soya meal. & $16 \%$ soya \\
& & leaves, $7 \%$ & $20 \%$ & meal. 18\% \\
& limestone & sorghum, & sorghum, \\
& & flour $(40 \%$ & $43 \%$ barley, & $7 \%$ \\
& & Ca) & $7 \%$ limestone & limestone \\
& & & flour (40\% & flour $(40 \%$ \\
& & & Ca). & Ca). \\
\hline
\end{tabular}

\section{(d) Feeding trials}

Twenty newly emerged adults of $A$. marginata, whose initial length, weights and aperture were taken, were randomly distributed into four dietary formulations in rearing boxes $(45 \times 25 \times 20 \mathrm{~cm})$. The snails were given feed worth $40 \%$ of their weights. The rearing boxes were made of wood. The boxes were covered with wire mesh of size $0.20 \mathrm{~mm}$. The boxes were kept in cool places under shade trees. The remnants of the feeds (those not consumed) were removed from the boxes and replaced with new ones everyday. Control trials were set up in which 20 newly emerged adults of $A$. marginata being fed with ( $40 \%$ body weight of the snail) water leaves and lettuce every everyday. The snails were kept inside boxes $(45 \times 25 \times 20 \mathrm{~cm})$. The boxes were covered with wire mesh of size $0.20 \mathrm{~mm}$. Each of these experiments occurred in triplicate and the experiments were monitored for 8 weeks. Data were collected at the end of every week on the weight, total length and aperture size of the snails. The weights were measured with an analytical weighing balance, threads were used to get the length and the aperture size and the threads were measured with a metre rule.

\section{Results and Discussion}

The results of the study revealed that giant land snail thrived well in diets B, C and D (Figs. 1, 2 and 3). The results of the various feed formulations revealed gradual gain in weight by the snails. Snails ate diets $\mathrm{A}$ and $\mathrm{B}$ readily being fresh vegetables but more growth was noticed in snails fed with diet B than in snails fed with diet A. Within a period of 8 weeks, snails fed with $\operatorname{diet} A$ recorded an increase in weight from $5 \mathrm{~g}$ to $19.4 \mathrm{~g}$. The snails fed with diet B performed better and recorded increase in weight from $5 \mathrm{~g}$ to $20.3 \mathrm{~g}$ within 8 weeks. The addition of oyster shell to diet B was responsible for the appreciable growth recorded for the snails. Thompson and Cheney (1996) reported that snails prefer juicy leaves and vegetables over dried ones and that calcium was very essential for snails' growth. They reported further that weekly supply of calcium to the diets of snails was very important for the development of the snails' shell and snails' growth.

There were tremendous improvements in the snails fed with Diets $C$ and $D$ because the snails recorded great increase in weight from $5 \mathrm{~g}$ to $30.2 \mathrm{~g}$ and $5 \mathrm{~g}$ to $36 \mathrm{~g}$ respectively (Fig. 1). Though all the feeds were relished by snails but diets $\mathrm{C}$ and $\mathrm{D}$ were able to supply the adequate nutritional requirements of the snails more appropriately. The higher protein contents of these feeds were responsible for the higher growth rate recorded for the snails fed with them. Murphy (2001) reported that snails' growth depended greatly on the level of protein intake and utilization. This corroborates what Ejidike (2004) reported that weight gain, protein efficiency ratio and feed conversion efficiency increased with increasing diet protein levels in Archachatina marginata. $\mathrm{He}$ reported further that Archachatina marginata hatchlings fed with lower diet protein level $(15 \%)$ performed significantly lower in growth.

The results of the various feed formulations on the body length of snails were more pronounced in diets $\mathrm{C}$ and $\mathrm{D}$ where increase in length from $1.5 \mathrm{~cm}$ to 6.3 $\mathrm{cm}$ and $1.5 \mathrm{~cm}$ to $6.5 \mathrm{~cm}$ were recorded respectively (Fig. 2). Though there is lack of agreement in several studies on dietary calcium in snail farming (Awesu, 1988; Awah, 1992; Ebenso and Okafor, 2002), Murphy (2001) reported that the range of calcium carbonate for the normal growth of snails was between $30 \%-40 \%$. This finding was corroborated 


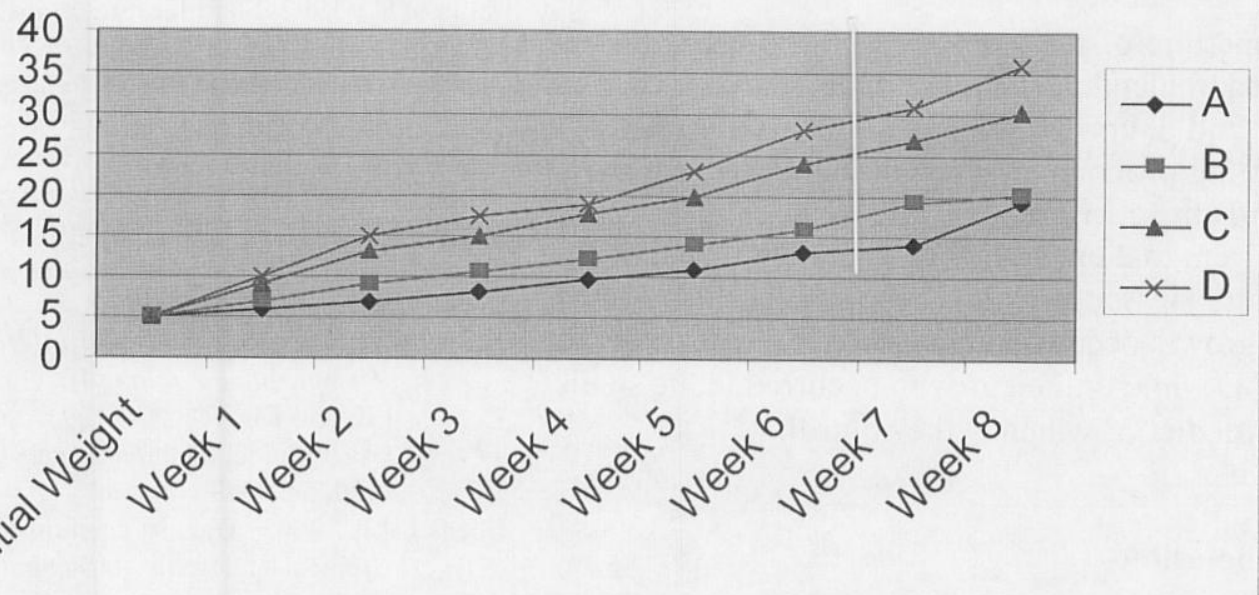

Fig. 1: Weight changes of snails in different diet formulations within 8 weeks

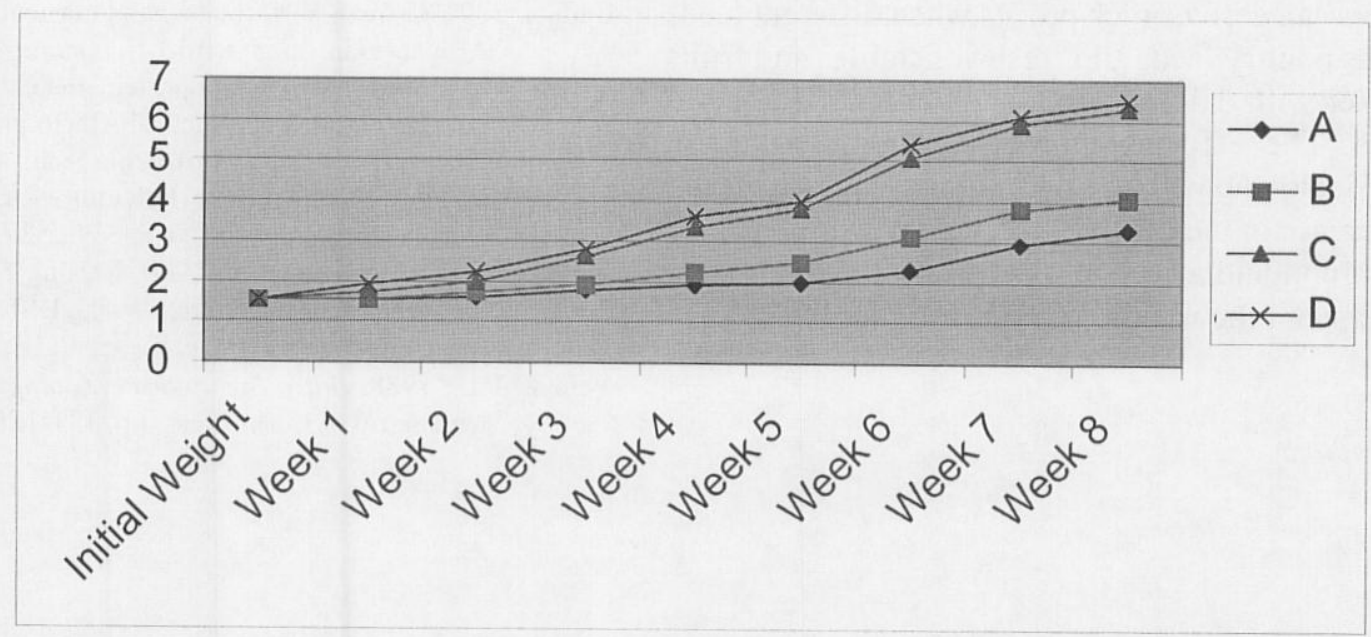

Fig. 2: Body length of snails fed with different diet formulations for 8 weeks

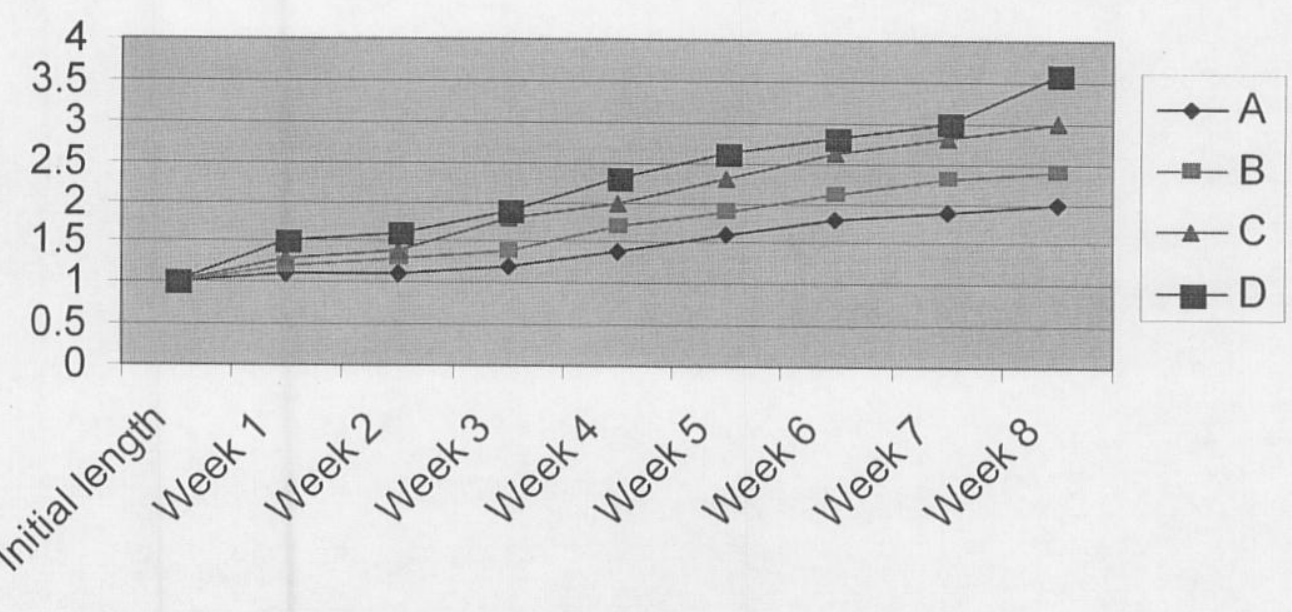

Fig. 3: Aperture length of snails fed with different diet formulations for 8 weeks 


\section{REFERENCES}

by Ebenso (2003) who reported that $20 \%$ oyster shell dietary supplement was the best for weight gains in Archachatina marginata.

The aperture of the snails fed with diets C and D showed tremendous increase in length from $1 \mathrm{~cm}$ to $3 \mathrm{~cm}$ and $1 \mathrm{~cm}$ to $3.6 \mathrm{~cm}$ respectively (Fig. 3 ) indicating pronounced growth. However, for diets $\mathrm{A}$ and $\mathrm{B}$ the aperture showed an increase in length from $1 \mathrm{~cm}$ to $2 \mathrm{~cm}$ and $1 \mathrm{~cm}$ to $2.4 \mathrm{~cm}$ respectively indicating lesser growth. These results showed that more growth occurred in the snails fed with diets B, $\mathrm{C}$ and $\mathrm{D}$ while limited growth occurred in the snails fed with $\operatorname{diet} \mathrm{A}$, which is the control.

\section{Conclusion}

Snails' meat is a delicacy sought after by both the rich and the poor because of its nutritional values. It is now evident that snail farming though an interesting job, is also a lucrative venture from which farmers can derive quick profits when different feeds such as poultry feeds and fresh vegetables and fruits together with daily calcium supplements are fed to snails. The efforts and perseverance of those individuals who will take on snail farming will ensure an increase in the availability of snails' meat all the year round and also boost the economy of peasant farmers and the nation as a whole.
Alexander, B.O., 1997. Snail and Snail Farming ( $1^{\text {st }}$ edition), Stirling-Horden Publishers Nigeria Ltd., Ibadan. pp.127.

Awah, A.A., 1992. Snail farming in mature rubber plantation: 1. Studies on aspects of specialized production techniques for farming Archachatina marginata. Snail Farming Research 4, 33-39.

Awesu, M.O., 1988. Observations on some aspects of reproduction of Archachatina marginata (Swainson) in captivity in a culture pen. Snail Farming Research $2,39-44$.

Becquaert, J.C., 1950. Studies in the Achatininae, a group of African land snails. Bulletin of the Museum of Comparative Zoology 105(1), 1-216.

Cooper, J.E. and Knowler, C., 1991. Snail and snail farming: An introduction for veterinary profession. Vet. Record, 129, 541-549.

Ebenso, I.E., 2003. Dietary calcium supplements for edible tropical land snails, Archachatina marginata in Niger Delta, Nigeria. Livestock Research for Development 15(5), 120-122.

Ebenso, I.E. and Okafor, N.M., 2002. Alternative diets for growing Archachatina marginata snails in southeastern Nigeria. Tropical Science 42 (3), 144-145.

Ejidike, 2004. Growth performance and nutrient utilization of African giant land snail (Archachatina marginata) hatchlings fed different protein diets. www.isfae.org/ jfae/2004/issue 1/abstracts/abstract6.php.

Murphy, B., 2001. Breeding and Growing Snails Commercially in Australia. Australian Heliculture Research Centre, 6 Crest Crescent. Moruya. NSW 2537.

Thompson, R. and Cheney, S., 1996. Raising Snails. Special Reference and Brief Series 96-05, USDA/ARS/NAL, Maryland. 42pp.

Yoloye, V.L., 1988. Basic Invertebrate Zoology ( $1^{\text {st }}$ edition). University of Ilorin Press. pp. 131-188. 